\begin{tabular}{|l|l|l||}
\hline \multicolumn{2}{|c|}{ PublisherInfo } \\
\hline \hline PublisherName & $:$ & BioMed Central \\
\hline \hline PublisherLocation & $:$ & London \\
\hline \hline PublisherImprintName & $:$ & BioMed Central \\
\hline \hline
\end{tabular}

\title{
Supplemental oxygen reduces wound infection
}

\begin{tabular}{|l|l|l||}
\hline \multicolumn{2}{|c|}{ ArticleInfo } \\
\hline \hline ArticleID & $:$ & 4189 \\
\hline \hline ArticleDOI & $:$ & $10.1186 /$ ccf-2000-4431 \\
\hline \hline ArticleCitationID & $:$ & 4431 \\
\hline \hline ArticleSequenceNumber & $:$ & 48 \\
\hline \hline ArticleCategory & $:$ & Paper Report \\
\hline \hline ArticleFirstPage & $:$ & 1 \\
\hline \hline ArticleLastPage & $:$ & 3 \\
\hline \hline & & RegistrationDate : 2000-2-25 \\
\hline ArticleHistory & $:$ & OnlineDate \\
\hline \hline ArticleCopyright & $:$ & Current Science Ltd2000-2-25 \\
\hline \hline ArticleGrants & $:$ & \\
\hline \hline ArticleContext & $:$ & 1305422 \\
\hline \hline
\end{tabular}




\section{Keywords}

Oxygen, perioperative, wound-infection

\section{Comments}

Supplemental oxygen in the perioperative period can be achieved simply and with minimal expense, and has been shown by this study to significantly reduce postoperative wound infection. However, no reductions in hospital stay were shown. The mechanism proposed by the authors (improved neutrophil bactericidal activity)requires validating because another possibility is that supplemental oxygen just reduces the number of anaerobic infections following colorectal surgery. It is not unusual for intensive care unit (ICU) patients to develop wound infections and it would have been interesting to know if those patients admitted to ICU all developed wound infections. In this case it could be argued that the ICU was the 'cause' of these wound infections and the results would be no longer significant if they were excluded.However, these are interesting results and if the mechanism is correct, then other infections may be reduced in situations of poor oxygen delivery to tissue.

\section{Introduction}

Wound infections following colorectal surgery may be influenced by perioperative factors such as the oxygen tension in tissue. Neutrophils defend the body against pathogens via oxidative killing, and so hypoxic wounds have weaker defences. Consequently, it may be possible to reduce wound infection by the perioperative administration of supplemental oxygen (thus ensuring wound hypoxia is avoided).

\section{Aims}

To investigate whether supplemental oxygen administration, during colorectal surgery, reduces the incidence of postoperative wound infection.

\section{Methods}


Five hundred patients undergoing elective colorectal surgery in three centres were randomised to receive $30 \%$ oxygen and $70 \%$ nitrogen, or $80 \%$ oxygen and $20 \%$ nitrogen intra-operatively. During the extubation period, oxygen concentration was increased to $100 \%$ and then reduced to previously predetermined levels (ie 30\% and 80\% respectively) as soon as it was felt safe to do so. For the first $2 \mathrm{~h}$ of recovery, oxygen was supplied via a non-rebreathing mask. Subsequently, patients breathed room air unless oxygen was required to maintain saturations $>92 \%$. Anaesthetic technique, fluid management, antibiotic administration etc were controlled for between the groups. The risk of infection was evaluated utilising two scoring systems (see article), and surgical wounds were examined daily by doctors blinded to the treatment groups. Pus was cultured, and wound healing and infection scored using the ASEPSIS system. In a subgroup of 54 patients, collagen and protein deposition in wounds was measured along with subcutaneous oxygen tensions.

\section{Results}

Baseline characteristics were similar, and intra-operative arterial oxygen saturation and partial pressure were significantly higher in the $80 \%$ oxygen group. Subcutaneous oxygen concentrations were also significantly higher intra-operatively, and in the $80 \%$ group in the $2 \mathrm{~h}$ recovery period. Scores for the risk of infection were similar in the two groups, but wound infections occurred in only 13 patients $(5.2 \%)$ in the $80 \%$ oxygen group, compared to 28 patients $(11.2 \%)$ in the $30 \%$ oxygen group. Mean ASEPSIS scores were significantly higher for those in the $30 \%$ oxygen group, but rates of healing and hospital stay were similar between the groups. Twelve and five patients in the $30 \%$ and $80 \%$ oxygen groups respectively were admitted to the ICU. Protein and collagen deposition didn't differ between the two groups in the analysed subgroup.

\section{Discussion}

Perioperative administration of supplemental oxygen reduces the incidence of wound infection during colorectal surgery. Since there were no differences in the extent of collagen deposition (scar formation), supplemental oxygen administration would not be expected to improve wound healing rates in the absence of infection. Subgroup analysis (30 patients) had previously shown that administration of $80 \%$ oxygen in the perioperative period had no effect on pulmonary function/atelectasis. The authors conclude that, by implementing this therapy, financial savings would be high.

\section{References}

1. Grief R, Akca O, Horn E-P, Kurz A, Sessler DI for the outcomes research group: Supplemental perioperative oxygen to reduce the incidence of surgical-wound infection. New Engl J Med. 2000, 342: 161-167. 